\title{
ТЕНДЕНЦІї ТА ПРОГНОЗ ПОШИРЕНОСТІ СТЕНОКАРДІЇ ТА ІНФАРКТУ МІОКАРДА В УКРАЇНІ
}

\author{
ДВНЗ «Тернопільський державний медичний університет імені І.Я. Горбачевського МОЗ України»
}

\begin{abstract}
Мета: вивчити динаміку показників поширеності та захворюваності населення України внаслідок стенокардії та інфраркту міокарда (IM) у регіональному аспекті протягом 1996-2014 років та спрогнозувати їх зміни до 2025 року.

Матеріали і методи. Матеріалом дослідження слугували дані Центру медичної статистики МОЗ України про рівень первинної захворюваності та поширеності стенокардії та ІМ серед населення України. У роботі використано епідеміологічний, демографічний, статистичний методи дослідження.

Результати. 3 використанням методу демографрічного районування проведено оцінку змін захворюваності й поширеності стенокардії та ІМ в Україні та окремих її районах протягом 1996-2014 років. Спрогнозовано тенденцію подальшого зростання даних патологій, як в Україні, так і в деяких її районах.

Висновки. Протягом останніх 18 років в Україні істотно зросла поширеність (у 2,9 разу) та захворюваність (у 1,5 разу) на стенокардію. Найбільше ці показники змінилися у Південному районі України. Дещо менше зросла поширеність IM - на 96,4\%. Прогнозні показники щодо захворюваності та поширеності стенокардії та IM свідчать про тенденцію їх зростання, особливо у Південно-Східному та Південному районах.
\end{abstract}

КЛЮЧОВІ СЛОВА: стенокардія, інфаркт міокарда, поширеність, первинна захворюваність, прогноз.

Життя сучасної людини насичене різноманітними психоемоційними навантаженнями, пришвидшеним темпом життя, шкідливими звичками, порушеним харчуванням. Це спонукає нашу серцевосудинну систему працювати в посиленому режимі, використовуючи свої адаптивні можливості. Як наслідок - зростання кількості серцево-судинних захворювань з тенденцією до їх неухильного збільшення в Україні [6].

Уже в 30-40-і роки XX ст. ураження серця та судин вийшли на перше місце за поширеністю і до наших днів залишаються основною причиною захворюваності та смертності в багатьох країнах світу. Якщо розглядати структуру цих уражень, то ішемічна хвороба серця займає провідне місце серед усієї патології серцево-судинної системи.

У 1962 р. Всесвітньою організацією охорони здоров'я (ВОО3) був запропонований термін «ішемічна хвороба серця» (IXC). У лютому 1969 р. виконавчий комітет ВООЗ вперше використав термін «епідемія» по відношенню до цієї патології. На даний час виділяють кілька фрорм ішемічної хвороби серця, найбільш небезпечними з яких вважаються стенокардія та інсраркт міокарда (IM).

Протягом останніх 20-30 років стенокардія та IM продовжують утримувати 4-5 місця у структурі захворюваності на серцево-судинну патологію [4;7]. Розвиток цих патологій пов'язаний із певними чинниками: статтю [4], віком [2], наявністю фракторів ризику, таких як артеріальна гіпертензія, гіперхолестеринемія, цукровий діабет, куріння, гіподинамія, загальне ожиріння. Часто спостерігається поєднання трьох і більше фракторів ризику [3;5]. Відмічено сезонну та погодну залежність серцево-судинної захворюваності на гострий IM (зимово-весняний період). Дестабілізація стенокардії найчастіше спостерігається в осінньо-зимовий період. [2].

Мета роботи - вивчити динаміку показників поширеності та захворюваності населення України на стенокардію та IM у регіональному аспекті протягом 1996-2014 років та спрогнозувати їх зміни до 2025 року.

Матеріали і методи. Матеріалом дослідження слугували дані галузевої статистичної звітності Центру медичної статистики МОЗ України про рівень первинної захворюваності та поширеності стенокардії та IM серед населення України.

У дослідженні використано демографічне районування [1;8]. Територіальною одиницею вибрано адміністративні області за такими ознаками, як показники відтворення населення та його віково-статевий склад, чисельність, особливості розміщення, розміри території. Виділено п'ять районів: Західний (Волинська, Закарпатська, ІваноФранківська, Львівська, Рівненська, Тернопільська та Чернівецька області), Центральний (Вінницька, Житомирська, Київська, Кіровоградська, Хмельницька і Черкаська області), Північно-Східний (Полтавська, Сумська і Чернігівська області), Південно-Східний (Дніпропетровська, Донецька, Запорізька, Луганська і Харківська області) та Південний (АР Крим, Миколаївська, Одеська і Херсонська області). 
У роботі використано епідеміологічний, демографрічний методи дослідження. Статистична обробка аналізів результатів дослідження проводилася із застосуванням комп'ютерних статистичних пакетів програм Statistica 6.0 та Microsoft Excel.

Результати дослідження та їх обговорення. На першому етапі дослідження було вивчено та згруповано дані щодо поширеності та первинної захворюваності на стенокардію та IM у регіональному аспекті протягом 1996-2014 років.

Загальна захворюваність на стенокардію в Україні зросла у 2014 р. порівняно із 1996 р. у 2,5 разу. Районні особливості зростання поширенос- ті цієї патології полягають в істотному зростанні іï у Південному районі 3 3309,0 до 11380,8 на 100 тис. нас. (у 3,4 разу) та у Північно-Східному з 3145,8 до 9479,0 на 100 тис. нас. (у 3,0 разу). У Західному районі спостерігається найменше зростання загальної захворюваності на стенокардію з 2873,9 на 100 тис. нас. у 1996 р. до 7333,6 на 100 тис. нас. у 2014 р. (2,4 разу) (табл. 1).

При детальнішому аналізі можна відмітити найвищі рівні загальної захворюваності на стенокардію в Україні за період 2010-2012 рр. із піком у 2011 р. (8 786,40 на 100 тис. нас.), які співвідносилися $з$ усіма регіонами.

Таблиця 1. Динаміка поширеності стенокардії в Україні за період 1996-2014 рр. (на 100 тис. нас.)

\begin{tabular}{|l|c|c|c|c|c|}
\hline \multicolumn{1}{|c|}{ Територія } & 1996 p. & 2000 p. & 2005 p. & 2010 p. & 2014 p. \\
\hline Україна & 3105,3 & 4900,3 & 7775,3 & 8707,5 & 7698,7 \\
\hline Південний район & 3309,0 & 5119,9 & 8149,7 & 10210,2 & 11380,8 \\
\hline Центральний район & 3174,1 & 5294,7 & 8109,1 & 9227,2 & 9065,0 \\
\hline Західний район & 2873,9 & 4642,3 & 6727,7 & 7406,3 & 7333,6 \\
\hline Південно-Східний район & 2788,0 & 4512,2 & 7415,8 & 8300,9 & $7777,5^{\star}$ \\
\hline Північно-Східний район & 3145,8 & 4859,7 & 8897,3 & 9488,3 & 9479,0 \\
\hline
\end{tabular}

Примітка. *Статистичні дані подані за 2013 рік через відсутність моніторингових даних з тимчасово окупованих територій Донецької і Луганської областей.

Серед областей можна відмітити найбільше зростанняпоширеностістенокардіїу Херсонській32385 на 100 тис. нас. до 12040,1 на 100 тис. нас. (5,0 разу), Запорізькій - 3 1882,5 на 100 тис. нас. до 8222,2 на 100 тис. нас. (4,4 разу) та Миколаївській - 3 2533,0 на 100 тис. нас. до 10485,0 на 100 тис. нас. (4,1 разу) областях. Найменші темпи збільшення загальної захворюваності на стенокардію в Україні за досліджуваний період спостерігалися у Львівській - з 3305,8 на 100 тис. нас. до 6179,1 на 100 тис. нас. (1,9 разу), Донецькій - з 3376,5 на 100 тис. нас. до 6591,8 на 100 тис. нас. (1,9 разу дані 2013 р.), Харківській - 33544,7 на 100 тис. нас. до 6988,0 на 100 тис. нас. (2,0 разу) областях.

Подібні тенденції спостерігалися і при вивченні динаміки первинної захворюваності на стенокардію в Україні протягом 1996-2014 років.
Так, первинна захворюваність стенокардією збільшилася в Україні в 2014 р. у 1,5 разу порівняно із 1996 роком. Найбільше вона зросла у Південному -3 328,0 на 100 тис. нас. до 907,6 на 100 тис. нас. (2,8 разу) та Південно-Східному - 3234,4 на 100 тис. нас. до 413,2 на 100 тис. нас. (1,8 разу) районах. Найменше змінилися показники первинної захворюваності у Західному - 3404,8 на 100 тис. нас. до 485,6 на 100 тис. нас. (1,2 разу) та ПівнічноСхідному - 3 350,8 на 100 тис. нас. до 445,6 на 100 тис. нас. (1,3 разу) районах. При цьому первинна захворюваність у Центральному районі у 1996 р. була нижчою порівняно із загальноукраїнськими даними - 276,8 на 100 тис. нас. і 296,8 на 100 тис. нас. (93,3\%) відповідно, а у 2014 р. уже перевищувала їх (відповідно 482,4 на 100 тис. нас. і 444,4 на 100 тис. нас. - 108,6\%) (табл. 2).

Таблиця 2. Динаміка захворюваності на стенокардію в Україні за період 1996-2014 рр. (на 100 тис. нас.)

\begin{tabular}{|l|c|c|c|c|c|}
\hline \multicolumn{1}{|c|}{ Територія } & 1996 р. & 2000 р. & 2005 р. & 2010 p. & 2014 p. \\
\hline Україна & 296,8 & 595,5 & 638,9 & 612,0 & 444,4 \\
\hline Південний район & 328,0 & 537,5 & 726,6 & 978,4 & 907,6 \\
\hline Центральний район & 276,8 & 583,5 & 607,0 & 581,9 & 482,4 \\
\hline Західний район & 404,8 & 565,1 & 658,5 & 578,6 & 485,6 \\
\hline Південно-Східний район & 234,4 & 432,7 & 577,4 & 512,6 & $413,2^{\star}$ \\
\hline Північно-Східний район & 350,8 & 662,8 & 632,3 & 544,7 & 445,6 \\
\hline
\end{tabular}

Примітка. *Статистичні дані подані за 2013 рік через відсутність моніторингових даних з тимчасово окупованих територій Донецької і Луганської областей. 
При оцінюванні динаміки первинної захворюваності на стенокардію за областями України за досліджуваний період виявлено істотне зростання патології у Миколаївській - 3249,8 на 100 тис. нас. до 1283,2 на 100 тис. нас. (5,1 разу), Хмельницькій 3 262,9 на 100 тис. нас. до 760,2 на 100 тис. нас. (2,9 разу) та Житомирській - 180,7 на 100 тис. нас. до 429,7 на 100 тис. нас. (2,4 разу) областях. Найменше зросла первинна захворюваність протягом 1996-2014 рр. у Волинській-3 288,2 на 100 тис. нас. до 306,0 на 100 тис. нас. (106,2\%) та Закарпатській областях - 3 652,2 на 100 тис. нас. до 694,5 на 100 тис. нас. (106,5\%) і навіть зменшилася у Чернівецькій області - 3 917,9 на 100 тис. нас. до 666,7 на 100 тис. нас. $(72,6 \%)$.
Також було вивчено дані щодо поширеності IM у регіональному аспекті протягом 1996-2014 років. У 2014 р. в Україні вона зросла порівняно із 1996 р. на 96,4\% (хоча у 2013 р. становила 112,9\%). Ці відмінності у 2013 та 2014 роках зумовлені складною ситуацією у тимчасово окупованих районах України.

Районні особливості зростання поширеності цієї патології полягають в істотному зростанні її у Центральному - з 93,8 до 133,6 на 100 тис. нас. (у 1,4 разу) та у Північно-Східному - 3 115,5 до 139,3 на 100 тис. нас. (у 1,2 разу) районах. У Південному районі спостерігається найменше зростання загальної захворюваності на IM - 3 110,8 на 100 тис. нас. у 1996 р. до 114,1 на 100 тис. нас. у 2014 р. (103,0\%) (табл. 3).

Таблиця 3. Динаміка поширеності ІМ в Україні за період 1996-2014 рр. (на 100 тис. населення)

\begin{tabular}{|l|c|c|c|c|c|}
\hline \multicolumn{1}{|c|}{ Територія } & 1996 p. & 2000 p & 2005 p. & 2010 p. & 2014 p. \\
\hline Україна & 120,2 & 115,5 & 130,8 & 132,6 & 115,9 \\
\hline Південний район & 110,8 & 100,9 & 118,8 & 117,8 & 114,1 \\
\hline Центральний район & 93,8 & 99,7 & 113,4 & 134,6 & 133,6 \\
\hline Західний район & 95,1 & 93,0 & 110,0 & 112,3 & 112,5 \\
\hline Південно-Східний район & 137,2 & 126,1 & 147,7 & 149,7 & $160,1^{*}$ \\
\hline Північно-Східний район & 115,5 & 124,6 & 131,7 & 134,1 & 139,3 \\
\hline
\end{tabular}

Примітка. *Статистичні дані подані за 2013 рік через відсутність моніторингових даних з тимчасово окупованих територій Донецької і Луганської областей.

Серед областей можна відмітити найбільше зростання поширеності IM у Хмельницькій 3 72,1 на 100 тис. нас. до 157,7 на 100 тис. нас. (2,2 разу), Кіровоградській - 104,6 на 100 тис. нас. до 164,4 на 100 тис. нас. (1,6 разу) та Тернопільській - 3 80,2 на 100 тис. нас. до 123,4 на 100 тис. нас. (1,5 разу) областях. Найменші темпи збільшення загальної захворюваності на IM в Україні за досліджуваний період спостерігалися у Харківській - $з 128,7$ на 100 тис. нас. до 132,5 на 100 тис. нас. (103,0\%) області, а у Львівській-3 153,1 на 100 тис. нас. до 111,2 на 100 тис. нас. (72,6\% разу) та Дніпропетровській - 158,3 на 100 тис. нас. до 151,7 на 100 тис. нас. (95,8\% разу) областях відмічалося навіть зменшення даного показника.

Другим етапом дослідження стало прогнозування динаміки поширеності та захворюваності на стенокардію та ІМ в Україні та по районах до 2025 року.

Прогнозні дані свідчать про тенденцію до зростання поширеності стенокардії в Україні. Так, загальноукраїнські показники поширеності прогнозовано зростуть з 7698,7 на 100 тис. нас. у 2014 р. до 13354,5 на 100 тис. нас. у 2020 р. (+73,5\%). У інших районах, де спостерігається найістотніше зростання загальної захворюваності на стенокардію за досліджуваний період, прогнозуються такі зміни. У Південному районі показник зміниться 3 11380,8 на 100 тис. нас. до 16987,3 на 100 тис. нас. $(+49,3 \%)$, у Північно-Східному - 39479,0 на 100 тис. нас. до 15443,5 на 100 тис. нас. (+62,9\%), у
Південно-Східному районі-з 7525,9 на 100 тис. нас. до 12833,1 на 100 тис. нас. (+70,5\%) (рис. 1).

Подібна тенденція спостерігається і при прогнозуванні первинної захворюваності на стенокардію. Так, загальноукраїнські показники зростуть із 444,4 на 100 тис. нас. у 2014 р. до 716,1 на 100 тис. нас. у 2025 р. (+61,1\%). Рівень первинної захворюваності прогнозовано найбільше зросте у Південно-Східному - з 352,9 на 100 тис. нас. до 620,4 на 100 тис. нас. (+75,8\%) та Південному 3907,6 на 100 тис. нас. до 1362,2 на 100 тис. нас. (+50,1\%) районах (рис. 2).

Щодо прогнозу поширеності IM, то рівень загальної захворюваності в Україні зросте із 115,9 на 100 тис. нас. у 2014 р. до 143,7 на 100 тис. нас. у 2025 р. (+24,0\%). Найбільше цей показник зросте у Центральному - 3 133,6 на 100 тис. нас. до 170,8 на 100 тис. нас. (+27,8\%), у Південно-Східному 3 146,7 на 100 тис. нас. до 173,6 на 100 тис. нас. (+18,4\%)таПівденномурайонах-3114,1на100тис.нас. до 133,7 на 100 тис. нас. $(+17,2 \%)$ (рис. 3).

\section{Висновки}

1. Поширеність стенокардії в Україні зросла у 2014 р. порівняно із 1996 р. у 2,9 разу. Найістотніше вона збільшилася у Південному (у 3,4 разу) та Північно-Східному (у 3,0 рази) районах України.

2. Захворюваність на стенокардію збільшилася в Україні у 2014 р. у 1,5 разу порівняно із 1996 роком. Найбільше вона зросла у Південному (у 2,8 разу) та Південно-Східному (у 1,8 разу) районах. 


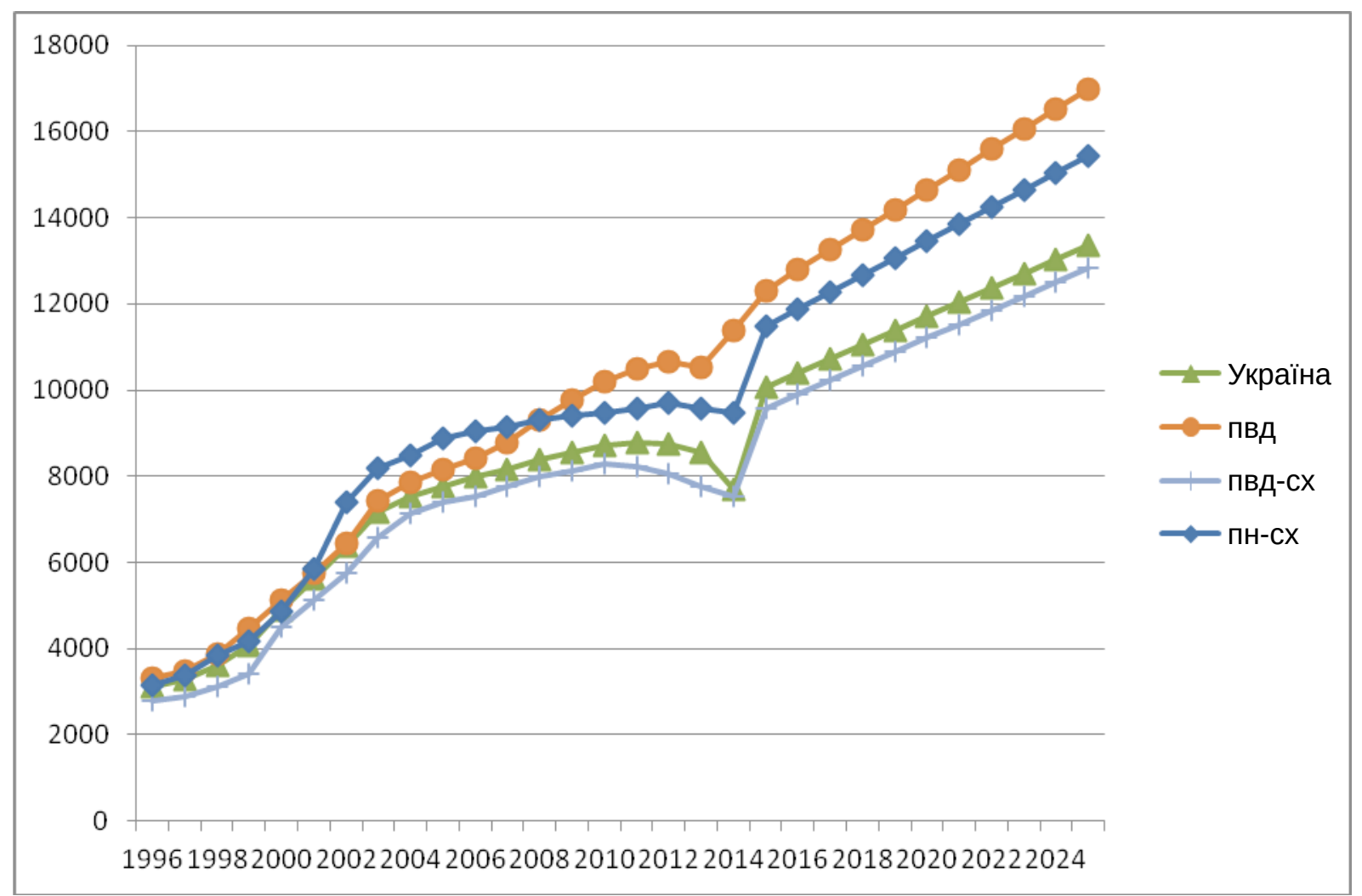

Puc. 1. Прогноз поширеності стенокардії в Україні та районах до 2025 року (на 100 тис. нас.)

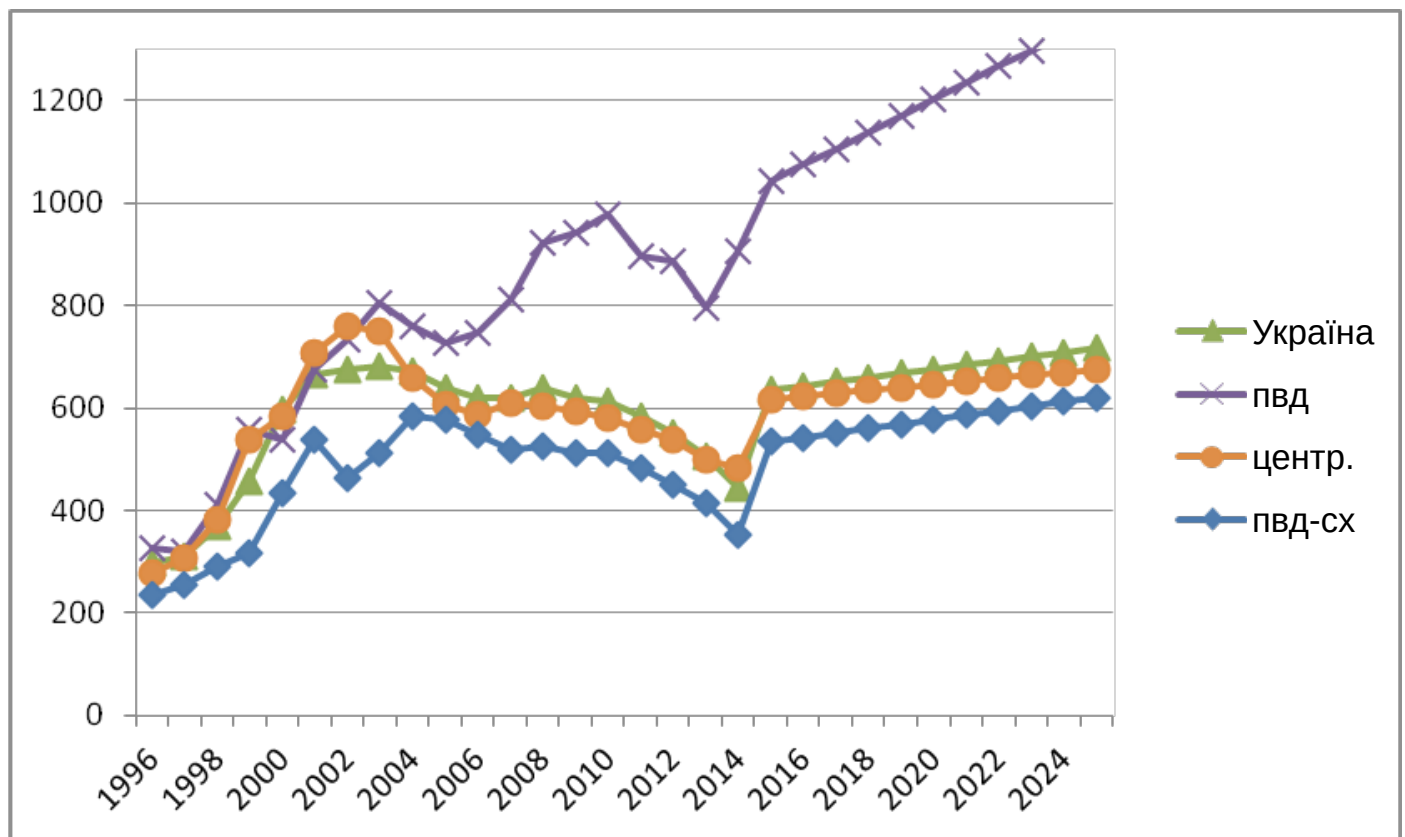

Рuc. 2. Прогноз захворюваності на стенокардію в Україні та районах до 2025 року (на 100 тис. нас.)

3. Поширеність IM в Україні зросла у 2014 р. порівняно із 1996 р. на 96,4\%. Найістотніше вона збільшилася у Центральному (у 1,4 разу) та Північно-Східному (у 1,2 разу) районах України.

4. Прогнозовано поширеність стенокардії в Україні до 2025 р. зросте на 73,5\%. Найбільше зростання очікується у Південно-Східному (70,5\%) та Північно-Східному $(62,9 \%)$ районах.
5. Первинна захворюваність на стенокардію прогнозовано збільшиться в Україні на 61,1\%, у Південно-Східному районі - на 75,8\%, у Південному - на 50,1\%.

6. Загальна захворюваність на IM прогнозовано зросте в Україні до 2025 р. на 24,0\%, у Центральному районі - на 27,8\%, у Південно-Східному - на 18,4\%, у Південному - на $17,2 \%$. 


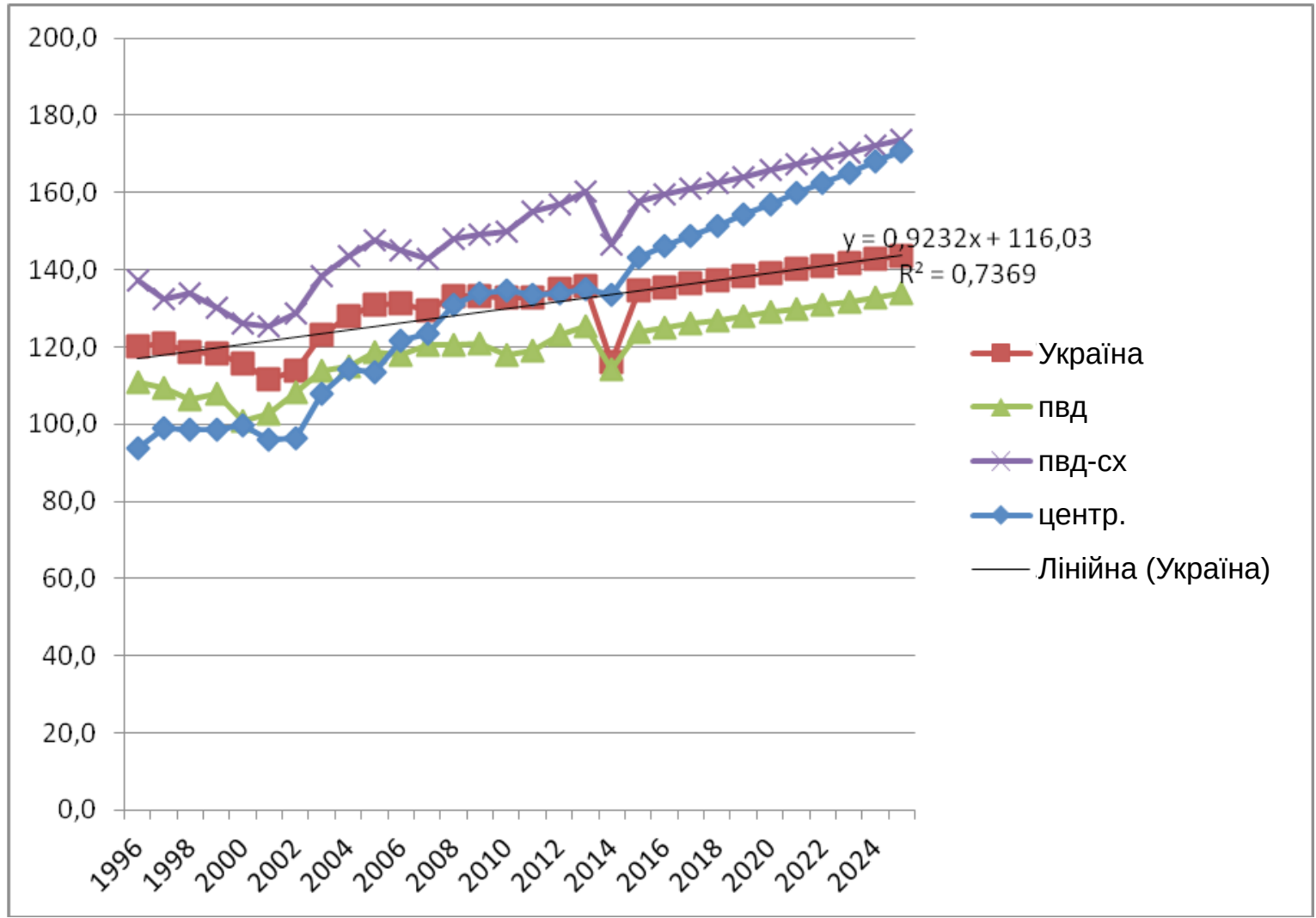

Рис. 3. Прогноз поширеності ІМ в Україні та районах до 2025 року (на 100 тис. нас.)

Перспективи подальших досліджень полягають у вивченні динаміки захворюваності та поши- реності основних захворювань серцево-судинної системи в Україні та їх прогнозі.

\section{Список літератури}

1. Демографрічна криза в Україні. Проблеми дослідження, витоки, складові, напрямки протидії / НАН України. ІН-т економіки; за. ред. Стешенко. - Київ, 2001. - 560 с.

2. Денефіль О. В. Серцево-судинна захворюваність населення м. Тернополя залежно від погодних умов / О. В. Денефріль // Вісник соц. гігієни та орг. охорони здоров'я України. - 2007. - № 4. - С. 17-21.

3. Горбась І. М. Фактори ризику серцево-судинних захворювань: поширеність і контроль / І. М. Горбась // [Електронний ресурс]. - Режим доступу: http://health-ua.com/article/2229.html. - Назва з екрану.

4. Крапівіна А. А. Захворюваність на хвороби системи кровообігу та їх поширеність серед дорослого населення України в 2010 році: гендерний аспект / А. А. Крапівіна // Україна. Здоров'я нації. - 2011. - № 4. - С. 12-18.

5. Поширеність основних фракторів ризику у хворих після інфаркту міокарда // І. М. Січкарук, Н. Д. Сидор, Ю. Г. Кияк [та ін.] // Запорожский медицинский журнал. - 2010. - Т. 12, № 4. - С. 37-41.

6. Теренда Н. О. Прогностична оцінка захворюваності та поширеності хвороб системи кровообігу / Н. О. Теренда // Вісник соц. гігієни та орг. охорони здоров'я України. - 2014. - № 4 (62). - С. 31-35.

7. Чепелевська Л. А. Регіональні особливості захворюваності населення України / Л.А. Чепелевська // Вісник соц. гігієни та орг. охорони здоров'я України. - 1999. - № 1. - С. 23-26.

8. Ященко Ю. Б. Динаміка захворюваності та смертності внаслідок хвороб системи кровообігу в Україні у регіональному аспекті / Ю. Б. Ященко, Н. Ю. Кондратюк // Вісник соц. гігієни та орг. охорони здоров'я України. - 2012. - № 3. - C. 25-29.

\section{ТЕНДЕНЦИИ И ПРОГНОЗ РАСПРОСТРАНЕННОСТИ СТЕНОКАРДИИ И ИНФАРКТА МИОКАРДА В УКРАИНЕ}

Н.А. Теренда

ГВУЗ «Тернопольский государственный медицинский университет имени И.Я. Горбачевского МЗ Украины»

Цель: изучить динамику показателей распространенности и заболеваемости населения Украины вследствие стенокардии и инфаркта миокарда (ИМ) в региональном аспекте на протяжении 1996-2014 годов и спрогнозировать их изменения до 2025 года. 
Материалы и методы. Материалом исследования послужили данные Центра медицинской статистики Минздрава Украины об уровне первичной заболеваемости и распространенности стенокардии и Им среди населения Украины. В работе использованы эпидемиологический, демографрический, статистический методы исследования.

Результаты. Используя метод демографического районирования, проведена оценка изменений распространенности и заболеваемости стенокардией и ИМ в Украине и отдельных ее районах в течение 1996-2014 годов. Спрогнозирована тенденция к дальнейшему росту стенокардии и ИМ как в Украине, так и в определенных ее районах.

Выводы. В течение последних 18 лет в Украине существенно возросла распространенность (в 2,9 раза) и заболеваемость (в 1,5 раза) стенокардией. Более всего эти показатели изменились в Южном районе Украины. Несколько меньше увеличилась распространенность ИМ - на 96,4\%. Прогнозные показатели по распространенности и заболеваемости стенокардией и ИМ свидетельствуют о тенденции к их увеличению, особенно в Юго-Восточном и Южном районах Украины.

КЛЮЧЕВЫЕ СЛОВА: стенокардия, инфраркт миокарда, распространенность, первичная заболеваемость, прогноз.

\section{PROGNOSTIC ESTIMATION OF INCIDENCE AND PREVALENCE OF DISEASES OF CIRCULATORY SYSTEM}

N.O. Terenda

SHEI «Ternopil State Medical University named after I. Gorbachevskyi Ministry of Health of Ukraine»

Purpose: to study dynamics of indicators of prevalence and morbidity of the population of Ukraine due to angina and myocardial infarction (MI) in regional aspect during 1996-2014 years and forecast their changes in 2025.

Materials and methods. As research materials were used the data of Center of Health Statistics of the Ministry of Health of Ukraine on the level of primary incidence and prevalence angina and $\mathrm{Ml}$ among the population of Ukraine. In work epidemiological, demographic, statistical methods of research are used.

Results. Using the method of demographic division estimation of changes in prevalence and incidence of angina and MI in Ukraine and its separate regions for 1996-2014 years has been spent. It is predicted tendency of further growth angina and $\mathrm{MI}$, both in Ukraine and in some districts.

Conclusions. Over the last 18 years in Ukraine prevalence and morbidity of angina and MI has significantly increased - 2,7 times and 1,7 times accordingly. More of these indicators have changed in Southern region of Ukraine. Prevalence MI increased by $96.4 \%$. Projected figures on prevalence and incidence angina and MI indicate a tendency of their growth, especially in Southeast and Southern regions.

KEY WORDS: angina, myocardial infarction, prevalence, primary incidence, forecast.

\section{Відомості про автора:}

Рукопис надійшов до редакції: 25.11.2015 p.

Теренда Наталія Олександрівна - к.мед.н., доцент кафедри соціальної медицини, організації та економіки охорони здоров'я з медичною статистикою дВНЗ «Тернопільський державний медичний університет імені І.Я. Горбачевського МО3 України»; тел.: +38(0352)-52-72-33. 